\title{
Field mapping of the early Proterozoic Karrat Group on Svartenhuk Halvø, central West Greenland
}

\author{
John Grocott and Reinoud Vissers
}

Field work on the Precambrian rocks of Svartenhuk Halvø was continued in 1983 in connection with the production of the 1:100 000 sheet $71 \mathrm{~V} .1 \mathrm{~N}$. The work was complementary to that of 1981 (van den Eeckhout \& Grocott, 1982), and attention was focussed on the middle and upper reaches of Kangiussap auvfâ in the east of Svartenhuk Halvø (fig. 10).

\section{Metasediments}

In the central part of the Rinkian mobile belt of West Greenland, early Proterozoic sediments of the Karrat Group overlie a gneiss complex. Within the Karrat group two formations have been recognised, the Qeqertarssuaq Formation and the overlying Nûkavsak Formation (Henderson \& Pulvertaft, 1967). Much of the study area is underlain by metamorphosed sandstones and shales of the Nûkavsak Formation, although in the south-west sediments are in contact with orthogneisses (van den Eeckhout \& Grocott, 1982). In the 1983 season superb exposures polished by ice, which revealed details of the sedimentary structures in psammitic beds normally invisible on the more usual lichen-covered outcrops, were examined. The clean outcrops also aided the study of facing-directions which has led to some new structural insights.

Sedimentary structures. These include grading, parallel and small-scale cross lamination, convolute lamination, and climbing ripples. Various examples were found of parts of Bouma sequences, and one bed has been observed with a complete sequence including coarse sandstone at the bottom ( $T_{\mathrm{a}}$ interval) grading into a parallel laminated psammite $\left(\mathrm{T}_{\mathrm{b}}\right)$, which passes upwards into a convolute layer with small-scale cross bedding $\left(\mathrm{T}_{c}\right)$, a vaguely laminated fine-grained psammite $\left(T_{d}\right)$, grading into a virtually structureless pelitic top $\left(T_{e}\right)$. At a few localities, channelling on a metre scale has been observed in rather thick psammite beds, some of which clearly amalgamate, though this is not general. Many of the beds consisting of $\mathrm{T}_{c-\mathrm{e}}$ intervals are relatively thin, and these beds in particular are observed to occur in bundles which in a few cases show clear thinning upwards. Flute cast-type bottom structures have only been observed at two localities; however, since the rocks are tightly folded, structures on bedding surfaces may have been destroyed during flexural slip.

Associations of brown-weathered metasediments. A small part of the sedimentary sequence is made up of associations of quartzites, carbonate rocks, amphibole schists and amphibolites. These rocks have been observed at three main localities and show a marked brown weathering colour. In the southern part of the study area adjacent to the basement gneiss the association has been documented by van den Eeckhout \& Grocott (1982). These rocks may represent members of the Qeqertarssuaq Formation which underlies the Nûkavsak Formation in the area south-east of Svartenhuk Halvø (Henderson \& Pulvertaft, 1967).

A conspicuous brown-weathered lithological association occurs as a marked ridge in the 


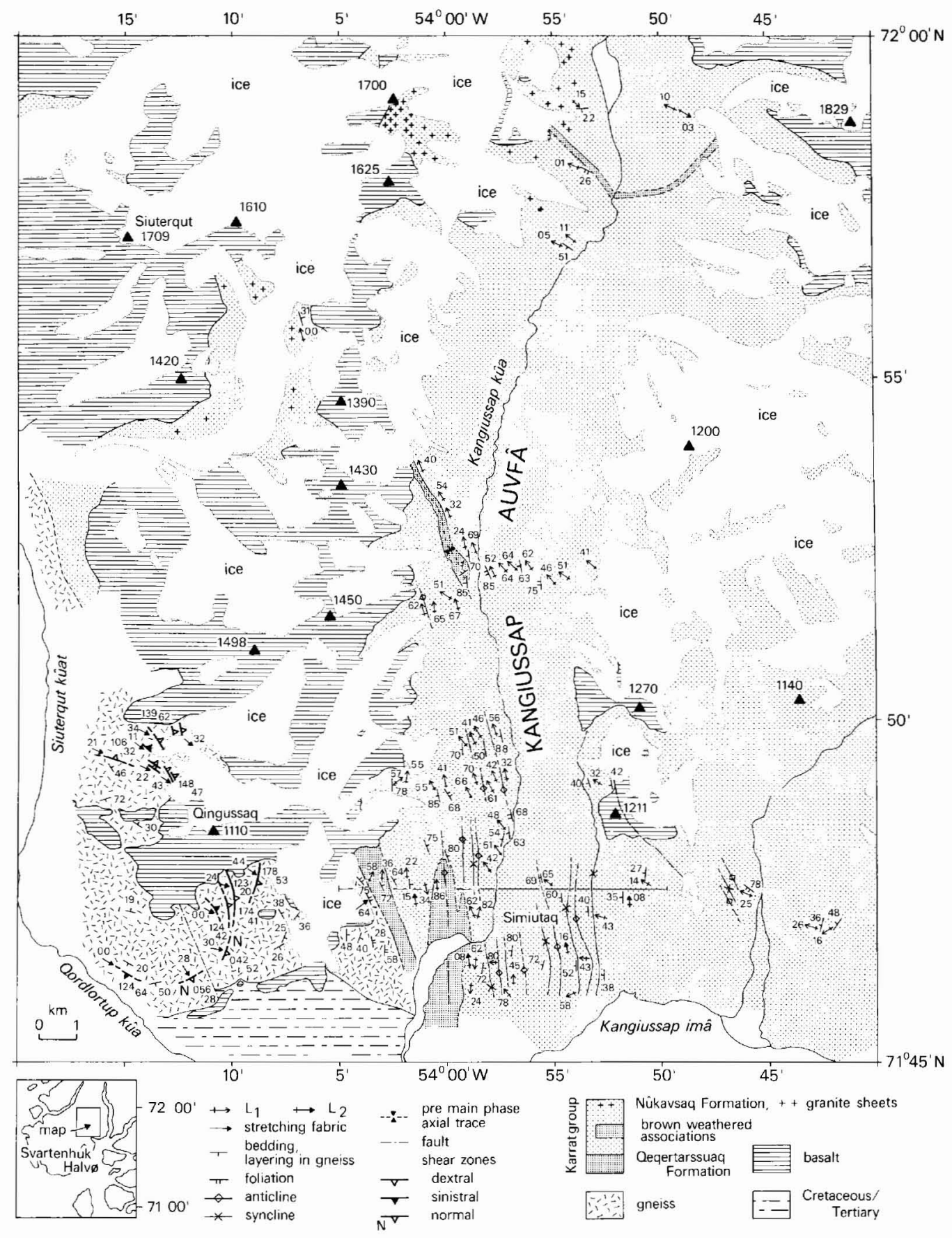

Fig. 10. Structural map of the Precambrian rocks of East Svartenhuk Halvø. 
topography on the west side of Kangiussap auvfâ at about $71^{\circ} 53^{\prime} \mathrm{N}$. An intimate association, up to $15 \mathrm{~m}$ thick, of brown-weathered quartzites, marbles and calc-silicate rocks is overlain by some $75 \mathrm{~m}$ of metavolcanic rocks including pillow basalts, pillow breccias and hyaloclastite tuffs (fig. 11). The brown-weathering colour clearly results from sulphide mineralisation in the quartzites, calc-silicates and lowermost $10 \mathrm{~m}$ of the volcanic sequence. Pyrrhotite makes up the bulk of the sulphides, but small amounts of pyrite and chalcopyrite occur. The pyrrhotite occurs both disseminated and in veins up to $2 \mathrm{~cm}$ thick. Notwithstanding deformation, primary crack structures, amygdales and pillow shapes are locally preserved (fig. 11), and way up could be determined in the pillow basalt. A few pillow basalt layers terminate bulbously in the bedding, and may represent lava tongues. Various beds of hyaloclastite show rythmic banding, possibly due to flow pulses. This association is underlain by sandstones and shales typical of the Nûkavsak Formation, and cannot therefore be attributed the Qeqertarssuaq Formation.

A third occurrence of quartzites, hornblende schists and carbonate and calc-silicate rocks has been noted in the northern part of the study area on both sides of the Kangiussap auvfâ valley at about $71^{\circ} 58^{\prime} \mathrm{N}$. The rocks occur in a brown-weathered layer up to $100 \mathrm{~m}$ thick within the Nûkavsak Formation. In addition to the rock types mentioned, a conglomerate layer of some three metres thick containing strongly deformed pebbles up to $1 \mathrm{dm}$ diameter was recognised. The calc-silicate rocks are mainly made up of diopside and actinolite, and contain remnants of strongly corroded fine-grained plagioclase-biotite rock. The amphibole schists and amphibolites did not yield relics of certain volcanic origin.

Depositional environment. The composition of the rocks and the internal structures of the beds indicate a submarine-fan depositional environment for the Nûkavsak Formation, in which sedimentation largely took place by turbidity currents. In contrast the lithologies of the Qeqertarssuaq Formation suggest deposition in a shelf environment (Henderson \& Pulvertaft, 1967). The rather rapid vertical transition from lithologies typical of the Qeqertarssuaq Formation to those of the Nûkavsak Formation indicates rapid subsidence at this stage.

In Svartenhuk Halvø absence of large channels, and the fact that amalgamation of $T_{a}$ intervals is not general, suggests an outer or mid-fan setting. The associations of brownweathered quartzites, marbles, calc-silicates and metavolcanics within the Nûkavsak Formation may be explained by a change in the depositional environment. One possibility indicated by the lithological similarities with the Qeqertarssuaq Formation is a reversion to shelf conditions. If this were the case, the detailed sedimentology of the sandstones and shales underlying these shelf-like associations should be consistent with the notion of the shelf periodically prograding into the Nûkavsak basin, but we do not know if this is so.

An alternative explanation for the brown-weathered associations within the Nukavsak Formation is that they were emplaced by a submarine slide involving sediments and volcanics which were the approximate time-stratigraphic equivalents of the underlying turbidites. Field evidence for this idea was found at the contact between the brown-weathered association and lithologies more typical of the Nûkavsak Formation at $71^{\circ} 53^{\prime} \mathrm{N}$ in Kangiussap auvfâ. At the southern limit of its outcrop the brown-weathered association rests discordantly on sandstones and shales of the Nûkavsak formation. At the contact a breccia comprising sub-rounded blocks of carbonate rocks up to $2 \mathrm{~m}$ diameter lying within a disrupted matrix of sandstone and shale was found. It is possible that this rock is a slide 

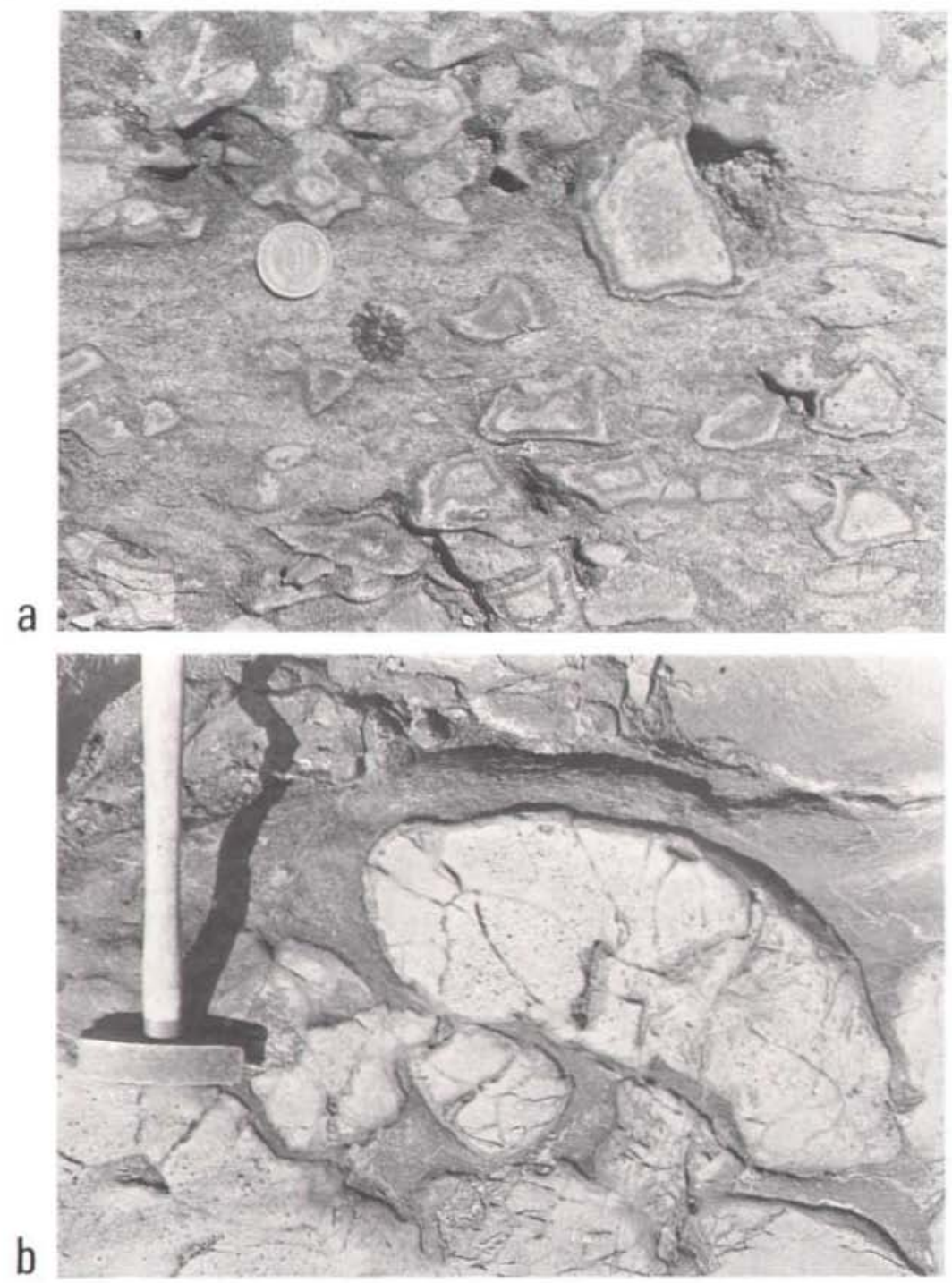

Fig. 11. Metavolcanic rocks from the brown-weathered lithological association occurring near latitude $71^{\circ} 53^{\prime} \mathrm{N}$ in Kangiussap auvfâ. (a) Hyaloclastite tuff. (b) Pillow breccia; the large pillow fragment right of centre exhibits joints reminiscent of cooling cracks.

breccia formed during emplacement of the brown-weathered association in the Nûkavsak basin.

Deformation. The beautifully exposed sections which facilitated examination of the sedimentary structures also assisted in the recognition of downward facing structures in the Nûkavsak Formation. This revealed the existence of pre-first cleavage folds, which occur at 


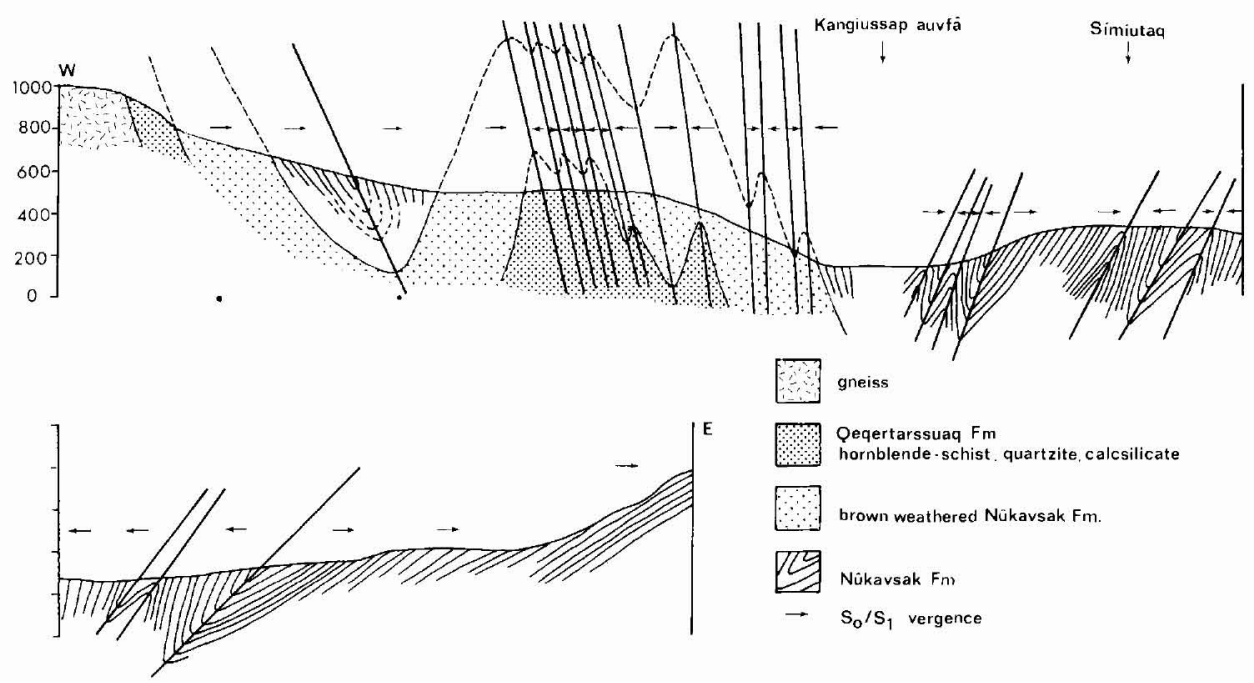

Fig. 12. Cross-section through Símiutaq in the south of the area. The line of section is shown on fig. 10 . Horizontal and vertical scales are equal.

outcrop, $500 \mathrm{~m}$ and $>5 \mathrm{~km}$ scale. The presence of these structures complicates work in the Nûkavsak Formation, not least because in areas of less than perfect exposure it is difficult to establish facing-directions.

In the 1981 field-work area the main cleavage was related to F1 folds, and, where they could be observed, sedimentary structures indicated that F1 folds were upward facing (van den Eeckhout \& Grocott, 1982). Downward-facing F1 folds were recognised in south-east Símiutaq, but this was related to rotation of $\mathrm{F} 1$ fold axes from subhorizontal through a reclined position in the axial plane during progressive D1 strain. No way-up criteria were found west of the hinge of the N-S trending F1 antiform west of Simiutaq, so that although the bedding/main cleavage vergence was consistently east no facing directions could be determined in this domain (see fig. 6, van den Eeckhout \& Grocott, 1982).

Our 1983 study began by reinvestigation of the structure in the critical ground between the antiform mentioned above and the contact with the gneisses. A distinctive rusty-weathered member is repeated by this fold and again by a synform before the gneiss contact is reached. As the bedding/main cleavage vergence is the same in both limbs of this newly identified synform, it must pre-date the adjacent antiform to the east (fig. 12).

Structures like this which are overprinted by the main D1 cleavage (S1), we call pre-main phase folds. We continue to refer to folds congruent with S1 as F1, and relate them to D1, the main phase deformation.

F1 structures identified in 1981 can be mapped into central Kangiussap auvfâ. The folds plunge moderately to steeply north, at most places parallel to the linear element of a shape fabric defined chiefly by biotite aggregates. Further north, the trend becomes NW and the plunge gentle WNW (fig. 10). The largest domain with downward-facing F1 folds has been recognised in the central parts of Kangiussap auvfâ. The direction of structural facing changes on each side of the metavolcanics which crop out on the west side of the valley at 
$\mathrm{S}$

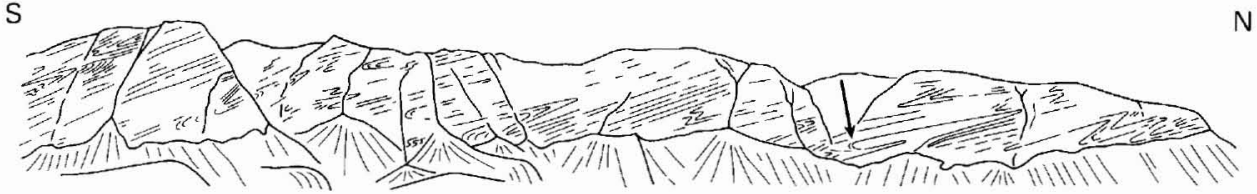

Fig. 13. Sketch of the cliff near latitude $71^{\circ} 58^{\prime} \mathrm{N}$ in Kangiussap auvfâ. Most of the structures are north vergent F1 folds. At the point indicated by the arrow, an interference pattern between a pre-main phase fold and an F1 fold is exposed. Length of cliff line is $3.5 \mathrm{~km}$, height of cliff is about $450 \mathrm{~m}$.

about $71^{\circ} 53^{\prime} \mathrm{N}$. Bedding/main cleavage vergence is generally north-east throughout the metavolcanics and associated rocks, and in the more typical Nûkavsak Formation lithologies on each side. This indicates that the metavolcanics occupy the core of a large-scale pre-main phase fold.

Further north in Kangiussap auvfâ the facing directions are upward on S1 at the few localities at which sedimentary structures were observed. North-east vergent F1 folds are well exposed in cliffs in the west side of the valley near $71^{\circ} 58^{\prime} \mathrm{N}$. At the north end of this cliff line these folds refold a $500 \mathrm{~m}$ scale pre-main phase fold (fig. 13).

A brief helicopter supported reconnaissance was made to the glacier valley south and east of Siuterqut (fig. 10). The bedding dips moderately north-east and probably passes via a synform to the south-west dips in the upper parts of Kangiussap auvfâ. The relationships along strike with structures in the vicinity of Símiutaq are concealed by ice and Tertiary volcanics.

The principal D2 structure recognised during the first field season steepens S1 and bedding westwards approaching the contact with the gneisses (fig. 12). This large scale antiform is associated with D2 crenulations, and locally, a D2 cleavage. In contrast with this relatively systematic D2 pattern in the south of the study area, crenulations are only sporadically developed further north, and their relation with the D2 structures to the south is uncertain.

Metamorphism. Thin section studies of samples collected in 1981 show that biotite occurs in the lower grade rocks in the south and east of the area, and persists as grade increases west towards the contact with the gneisses. In the south of the area traversing west, andalusite first appears with staurolite in rocks of appropriate composition in east Símiutaq. Biotite mineral and shape fabrics together with a form orientation of quartz and feldspar define L1 and S1. Staurolite and andalusite overgrew these fabrics which form fine-grained straight inclusion trails in the porphyroblasts. West of Kangiussap auvfâ andalusite forms rims around staurolite, and inclusion trails exhibit D2 crenulations in the outer domains of some andalusite porphyroblasts. Within $1 \mathrm{~km}$ of the gneiss contact sillimanite occurs in migmatitic pelitic horizons containing white mica as well as biotite. Garnet is found in the rocks attributed to the Qeqertarssuaq Formation in the core of the antiform east of Simiutaq, but it is rare in the Nûkavsak Formation. Like andalusite garnet overgrew fine-grained straight S1 inclusion trails.

Andalusite is widespread in pelitic rocks of appropriate composition in central Kangiussap auvfâ. Further north sillimanite fibres become visible in hand specimens. This increase in metamorphic grade is reflected in the mineralogy of calc-silicate horizons occurring in the 
brown-weathered associations. To the south these are characterised by actinolite and tremolite, whilst in the north diopside occurs.

\section{Granite sheets}

In the north part of Kangiussap auvfâ a zone of two mica-garnet granite sheets cuts the Nûkavsak Formation. At valley floor level the proportion of sheets is 10 per cent, but this increases upwards, so that the top $300 \mathrm{~m}$ of the peak $1700 \mathrm{~m}$ to the west consists almost entirely of granite sheets. As the sediments became invaded by the sheets they did not lose continuity, as even where the proportion of intruded material exceeds 75 per cent screens of sediments, apparently isolated in two dimensions, have not rotated with respect to each other.

The sheets can be traced as a zone to the south-west, where they occur in the valley south and east of Siuterqut, and to the north-east where they are exposed in the upper reaches of Uvkusigssat fjord. In upper Kangiussap auvfâ, most sheets dip gently north-west at a consistent small angle to the bedding, but more than one orientation set may be present.

The granite sheets cut F1 folds, but contain a planar fabric parallel to $\mathrm{S} 1$ in the sediments. L1 in the sheets is also parallel to L1 in the sediments. The sheets were therefore intruded during D1. In the S part of the study area, west of Simiutaq, similar granite sheets post-date D1.

\section{Structural history of the metasediments}

(1) Formation of pre-main phase folds with, at least locally, a related cleavage. Metamorphic conditions at this time were probably low grade.

(2) Main phase deformation (D1), formation of F1 and S1. F1 axes are usually parallel to L1. Garnet and staurolite growth was syn- to post-D1, andalusite grew syn- to post-D1 to syn-D2, while sillimanite grew syn-D1.

(3) Syn-D1 intrusion of two mica-garnet granite sheets in a gently north-west dipping, NE-SW trending zone in the north of the area.

(4) D2 folding leading to steepening of S1 and bedding from east to west in the south of the area and from north-east to south-west. To the north-west, towards higher structural levels, this D2 antiform dies out under ice and Tertiary basalts.

Acknowledgements. Logistic support was provided by J. F. Johnstrup with Andreas Viðstein as skipper, and a Greenlandair Charter helicopter. Troels Nielsen co-ordinated the field work. We are grateful to all concerned for their help. Bas van den Eeckhout is thanked for his constructive criticism of the manuscript.

\section{References}

Eeckhout, B. van den \& Grocott, J. 1982: Investigations on the Precambrian rocks of Svartenhuk Halvø, central West Greenland. Rapp. Grønlands geol. Unders. 110, 22-26.

Henderson, G. \& Pulvertaft, T. C. R. 1967: The stratigraphy and structure of the Precambrian rocks of the Umanak area, West Greenland. Meddr dansk geol. Foren. 17, 1-20.

J. G.,

Geologisch Instituut,

R. $V$.,

Universiteit van Amsterdam,

Nieuwe Prinsengracht 130,

$1018 \mathrm{VZ}$ Amsterdam

The Netherlands.

Instituut voor Aardwetenschappen,
Rijksuniversiteit Utrecht,
Budapestlaan 4,
3508 TA Utrecht,
The Netherlands.

